\title{
Morphology and morphometry of Haemonchus contortus exposed to Gigantochloa apus crude aqueous extract
}

\author{
Budi Purwo Widiarso ${ }^{1,2}$, Kurniasih Kurniasih ${ }^{3}$, Joko Prastowo ${ }^{4}$ and Wisnu Nurcahyo
}

1. Doctoral Program Parasitology Department, Faculty of Veterinary Medicine, Universitas Gadjah Mada, Yogyakarta 55281, Indonesia; 2. Department of Animal Health, Agriculture Extension College (STPP), Magelang, Jalan MagelangKopeng Km 7 Purwosari, Tegalrejo, Magelang, Jawa Tengah, 56192, Indonesia; 3. Department of Pathology, Faculty of Veterinary Medicine, Universitas Gadjah Mada, Bulaksumur, Yogyakarta 55281, Indonesia; 4. Department of Parasitology, Faculty of Veterinary Medicine, Gadjah Mada University, Bulaksumur, Yogyakarta 55281, Indonesia.

Corresponding author: Wisnu Nurcahyo, e-mail: wisnu-nc@ugm.ac.id

Co-authors: BPW: budipw2000@yahoo.com, KK: kurniasih@ugm.ac.id, JP: joko2465@yahoo.com

Received: 22-03-2018, Accepted: 30-05-2018, Published online: 14-07-2018

doi: 10.14202/vetworld.2018.921-925 How to cite this article: Widiarso BP, Kurniasih K, Prastowo J, Nurcahyo W (2018) Morphology and morphometry of Haemonchus contortus exposed to Gigantochloa apus crude aqueous extract, Veterinary World, 11(7): 921-925.

\begin{abstract}
Aim: Haemonchus contortus is the most pathogenic nematode infesting the digestive tract of goats and sheep worldwide leading to a tremendous loss in a variety of routes. Economic losses due to haemonchosis in subtropic and tropic areas are usually caused by poor weight gain, minimized growth, loss of production, and mortality. The prevalence of haemonchosis in Indonesia is $89.4 \%$ in goat, and annual loss achieved 1 million US dollars. This study evaluated in vitro effects of Gigantochloa apus crude aqueous extract as an anthelmintic on H. contortus morphology and morphometry.

Materials and Methods: Bligon goats which are naturally infected were collected from slaughtered goat from local slaughterhouses, namely Besi Sleman. Bligon goat's abomasum part was carefully examined and transported to the Parasitology Laboratory, University of Gadjah Mada, Yogyakarta. H. contortus was obtained from 4 to 6-month-old female goat from slaughterhouses in Yogyakarta area. H. contortus was collected from abomasum and put into a Petri dish containing $0.62 \%$ water saline. The number of $H$. contortus used for each concentration is 25 . H. contortus was soaked in each concentration for $4 \mathrm{~h}$. The figure of the parasites or parts of parasites was captured using camera Lucida, and they were measured using both objective micrometer and objective ocular micrometer. All the capturing processes were done with the help of Olympus Digital Camera under Olympus CX21 microscopic. Parasite morphology was identified in morphological and morphometric characters.
\end{abstract}

Results: Morphology of $H$. contortus revealed the cervical papillae bulge appears unclear shape and anterior end is more tapered. Vulvar flab control is not tapered, but vulvar flab which gets aware of G. apus crude aqueous extract looks more pointed. The gubernaculum appears irregular compared to gubernaculum control which tends to be more compact, and the posterior end form appears irregular more than posterior end control. Morphometry study of $H$. contortus indicates that it has a significant difference for body length, body width, cervical papillae, and spicule length in the male.

Conclusion: G. apus crude aqueous extract activity revealed morphology change such as cervical papillae, vulvar flab, gubernaculum, posterior end, and reduced morphometry measurement of $H$. contortus adult worms, notably in body length, body width, cervical papillae width, gubernaculum, and spicule length in males and body length, body width, cervical papillae width, and vulva length in females.

Keywords: bligon goat, crude aqueous extract, Haemonchus contortus, morphology, morphometry.

\section{Introduction}

Haemonchus contortus is the most pathogenic nematode infesting the digestive tract of goats and sheep worldwide. It leads to a tremendous loss in a variety of routes [1]. Poor weight gain, retarded growth, loss of production, and mortality usually cause economic losses because of haemonchosis in subtropic and tropic areas [2,3]. The prevalence of

Copyright: Widiarso, et al. Open Access. This article is distributed under the terms of the Creative Commons Attribution 4.0 International License (http://creativecommons.org/licenses/ by/4.0/), which permits unrestricted use, distribution, and reproduction in any medium, provided you give appropriate credit to the original author(s) and the source, provide a link to the Creative Commons license, and indicate if changes were made. The Creative Commons Public Domain Dedication waiver (http:// creativecommons.org/publicdomain/zero/1.0/) applies to the data made available in this article, unless otherwise stated.
Haemonchosis in Indonesia is $89.4 \%$ in goat, and annual loss achieved 1 million US dollars [4].

For decades, the use of anthelmintic chemicals for the therapy of gastrointestinal nematode infections in cattle has present of drug resistance. In addition to spending a considerable cost to find new types, anthelmintic also often poses a problem for the safety of food products of animal origin [5]. Anthelmintic resistance is responded by making the discovery of natural substances with low toxicity to reduce the burden of worms in livestock [6]. Many innovations are made to find alternatives to anthelmintic by selecting some plants that contain tannin because it is reported that the substance can reduce the incidence of worm infestation. The development of new anthelmintics suggests that plants containing tannin (Tannin plants) 
can be considered as potential strategic alternatives for the control of nematode infestation in small ruminants [7]. Plant biological resources have been widely used by breeders and researchers to help to increase the growth of their farms. One source of biological tanninferous plants that can be a new alternative is the use of bamboo leaves to help the farm business [8]. Gigantochloa apus crude aqueous extract was made by chopping bamboo leaves into smaller pieces. Chopped apus bamboo leaves were weighed according to the desired weight or concentration, which was $1 \mathrm{~g}$ and $10 \mathrm{~g}$ for stock solutions. Both chopped apus bamboo leaves are put into separate beakers. The beakers filled with bamboo leaves were then filled with $100 \mathrm{ml}$ of Aquadest. The beakers were then put into an oven with a temperature of $90^{\circ} \mathrm{C}$ for $15 \min$ [9].

This study evaluated in vitro effects of G. apus crude aqueous extract as an anthelmintic on $H$. contortus morphology and morphometry.

\section{Materials and Methods \\ Ethical approval}

All stages of the research were approved by the Ethical Committee of Gadjah Mada University (number 00118/04/LPPT/IX/2017).

\section{Tools and materials}

The research materials include tools and materials used during the research. The tools used are as follows: Petri dish to observe adult worms' motility and mortality rate, object glass to make worm preparation, microscope to observe part of the worm, camera Lucida to paint the worm, stopwatch to measure Haemonchus killing time submerged by $G$. apus crude aqueous extract, oven to make apus bamboo crude aqueous extract, Erlenmeyer flask to make apus bamboo crude aqueous extract in various dosages, electric scale to measure bamboo leaf weight, surgical scissors to cut off the abomasal line for worms exploring, and the length and body part of $H$. contortus were measured by micro caliper. The materials used are G. apus crude aqueous extract, $H$. contortus adult worm, Aquadestilata, ethanol, and $0.62 \% \mathrm{NaCl}$. Morphometric test of $H$. contortus uses concentration at $0,0.1$, and $1 \mathrm{mg} / \mathrm{ml}$ to find the lowest effective dose of killing the worms as a dose base determination for in vivo research.

\section{Parasites collection}

Bligon goats which are naturally infected were collected from slaughtered goat from local slaughterhouses, namely Besi Sleman. Bligon goat's abomasum part was carefully examined and transported to the Parasitology Laboratory, University of Gadjah Mada, Yogyakarta. H. contortus was obtained from 4 to 6-month-old female goat from slaughterhouses in Yogyakarta area. H. contortus was collected from abomasum and put into a Petri dish containing $0.62 \%$ water saline. The number of $H$. contortus used for each concentration is 25 . H. contortus was soaked in each concentration for $4 \mathrm{~h}$.
The figure of the parasites or parts of parasites was captured using camera Lucida, and they were measured using both objective micrometer and objective ocular micrometer. All the capturing processes were done with the help of Olympus Digital Camera under Olympus CX21 microscopic. Parasite morphology was identified in morphological and morphometric characters [6].

\section{G. apus crude aqueous extract}

In making $1 \%$ G. apus crude aqueous extract, according to Daryatmo et al. [9], crude aqueous extract of apus bamboo leaves was made by chopping bamboo leaves into smaller pieces. Chopped apus bamboo leaves were weighed according to the desired weight or concentration, which was $1 \mathrm{~g}$ and $10 \mathrm{~g}$ for stock solutions. Both chopped apus bamboo leaves are put into separate beakers. The beakers filled with bamboo leaves were then filled with $100 \mathrm{ml}$ of Aquadest. The beakers were then put into an oven with a temperature of $90^{\circ} \mathrm{C}$ for $15 \mathrm{~min}$. The remaining liquid in the beakers was taken and filtered to obtain a concentration of $0.1 \%$ and $1 \%$ G. apus crude aqueous extract.

\section{Statistical analysis}

Morphology of $H$. contortus adult worms at various concentrations was determined by microscopic observation. The differences in morphometry variables of $H$. contortus were recorded and analyzed using SPSS software 16.0.

\section{Results}

\section{G. apus leaf crude aqueous extract on morphology of female and male $\boldsymbol{H}$. contortus adult worms}

Comparative characteristics are shown in Figures-1-4. The body is filiform (slender) tapering toward the anterior end in male and female. The anterior end is relatively wide and blunt. The buccal cavity is small with a conspicuous tooth extending from the dorsal wall. There are no buccal capsules. In addition to transverse striation, longitudinal lines are also present on the body.

Figure-1 shows that cervical papillae in control (a) appear clearly and conspicuous and part of cervical papillae at the concentration of $1 \mathrm{mg} / \mathrm{ml}$ (b) and $0.1 \mathrm{mg} / \mathrm{ml} \mathrm{(c).} \mathrm{The} \mathrm{anterior} \mathrm{end} \mathrm{is} \mathrm{more} \mathrm{tapered,} \mathrm{and}$ the cervical papillae bulge appears unclear shape.

Figure-2 observes that vulvar flab control is not tapered (a). Vulvar flab which gets aware of G. apus concentration of $0.1 \mathrm{mg} / \mathrm{ml}$ and $1 \mathrm{mg} / \mathrm{ml}$ crude aqueous extract of G. apus looks more pointed. Vulvar flab in concentration of $1 \mathrm{mg} / \mathrm{ml}$ is sharpener and cleaner than $0.1 \mathrm{mg} / \mathrm{ml}$ concentration.

Figure-3 shows that gubernaculum form exposed to $G$. apus (b/c) appears irregular compared to control gubernaculum which tends to be more compact. Spiculas exposed to G. apus appear more budding than control spicula.

Figure-4 shows that the posterior end form exposed to G. apus crude aqueous extract at a concentration of $0.1 \mathrm{mg} / \mathrm{ml}$ and $1 \mathrm{mg} / \mathrm{ml}$ appears irregular (b/c) more than posterior end control. 


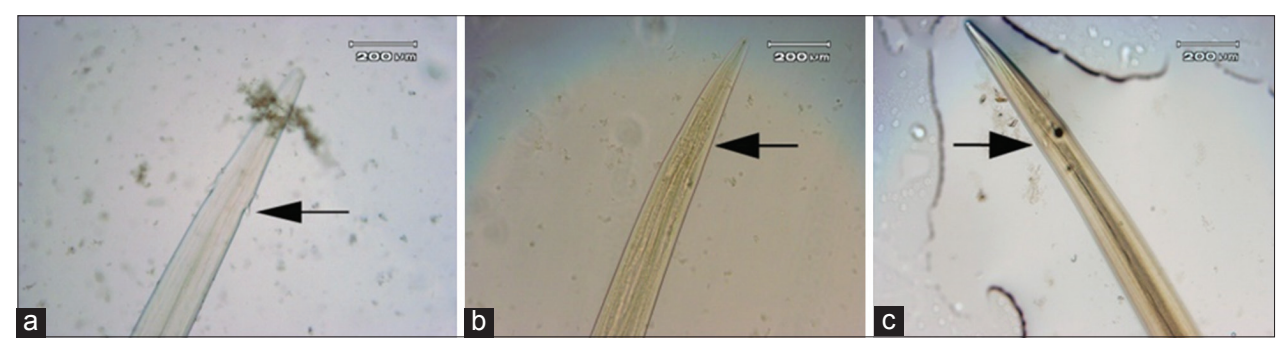

Figure-1: Morphology cervical papillae: (a) Cervical papillae which is not soaked in Gigantochloa apus crude aqueous extract; (b) cervical papillae which is soaked in G. apus crude aqueous extract $0.1 \mathrm{mg} / \mathrm{ml}$ concentration; (c) cervical papillae which is soaked $G$. apus crude aqueous extract $1 \mathrm{mg} / \mathrm{ml}$ concentration.
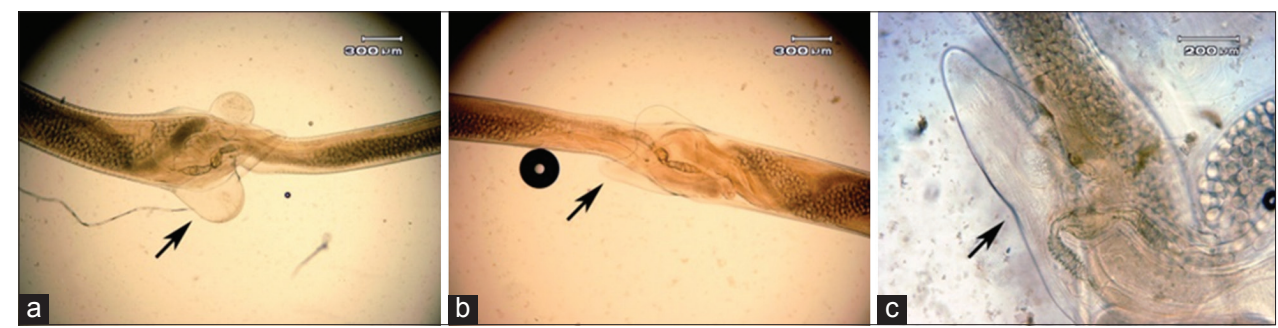

Figure-2: Morphology of vulvar flab: (a) Vulvar flab which is not soaked in Gigantochloa apus crude aqueous extract; (b) vulvar flab which is soaked in G. apus crude aqueous extract $0.1 \mathrm{mg} / \mathrm{ml}$ concentration; (c) vulvar flab which is soaked in $\mathrm{G}$. apus crude aqueous extract $1 \mathrm{mg} / \mathrm{ml}$.
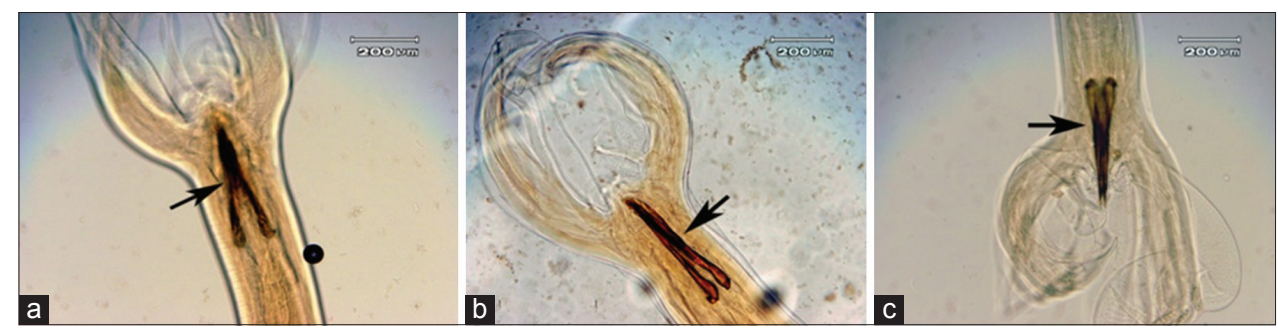

Figure-3: Morphology of gubernaculum: (a) Gubernaculum which is not soaked in Gigantochloa apus crude aqueous extract; (b) the gubernaculum which is soaked in G.apus crude aqueous extract at a concentration $0.1 \mathrm{mg} / \mathrm{ml}$; (c) gubernaculum which is soaked in G.apus crude aaqueous extract with concentration of $1 \mathrm{mg} / \mathrm{ml}$.
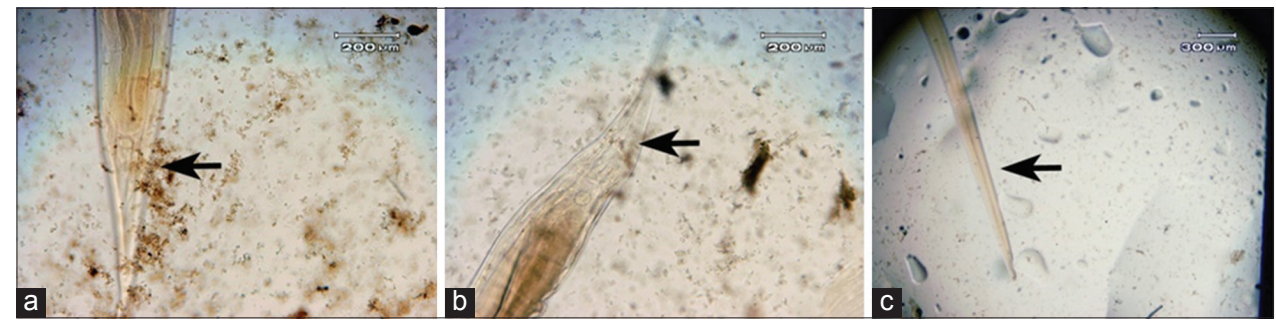

Figure-4: Morphology of posterior end: (a) Posterior end which is not soaked in Gigantochloa apus crude aqueous extract; (b) posterior end which is soaked in G. apus crude aqueous extract at concentration $0.1 \mathrm{mg} / \mathrm{ml}$; (c) posterior end which is soaked in $G$. apus crude aqueous extract with concentration $1 \mathrm{mg} / \mathrm{ml}$.

\section{Apus bamboo leaf crude aqueous extract on mor- phometry of female and male $H$. contortus adult worms}

The result reports that bamboo leaf crude aqueous extract affects morphometry of female and male $H$. contortus adult worms such as body length of the worm, body width of the worm, cervical papillae width, spicule length, gubernaculum length, and vulva length (Tables-1 and 2).

Morphometry of female $H$. contortus produces a body length and body width of $27.25 \pm 2.59 \mathrm{~mm}$ and $0.64 \pm 0.08$, respectively. Vulva is located in the posterior third of the body at a distance of about
$4.67 \pm 0.31 \mathrm{~mm}$ from the posterior end. The vulvular lips are inconspicuous, but a linguiform process is invariably present. Vulva is covered with valves.

Morphometry of male $H$. contortus produces a body length and body width of $17.25 \pm 0.79 \mathrm{~mm}$ and $0.29 \pm 0.06$, respectively. The tail end bears a bursa. The bursa consists of three lobes, two large lateral lobes, and poorly developed dorsal lobe. Dorsal ray is asymmetrical and bifurcated. Externo-dorsal ray is thin and long. Lateral rays arise from a common trunk, and ventral rays are fused proximally and separated dorsally.

The result of microscopic observation on $H$. contortus adult worms indicates that it has a significant 
Table-1: Morphometry of female $H$. contortus adult worms due to the administration of bamboo leaves crude aqueous extract in vitro.

\begin{tabular}{lccc}
\hline Worm morphometry & Control (0\%) & $\begin{array}{c}\mathbf{0 . 1} \mathbf{~ m g / m l ~ G . ~ a p u s ~ c r u d e ~ a q u e o u s ~} \\
\text { extract } \mathbf{( m m )}\end{array}$ & $\begin{array}{c}\mathbf{1} \mathbf{~ m g / m l ~ G . ~ a p u s ~ c r u d e ~ a q u e o u s ~} \\
\text { extract } \mathbf{( m m})\end{array}$ \\
\hline Body length & $27.25 \pm 2.59^{\mathrm{a}}$ & $26.30 \pm 1.75^{\mathrm{b}}$ & $24.30 \pm 1.85^{\mathrm{c}}$ \\
Body width & $0.64 \pm 0.08^{\mathrm{a}}$ & $0.48 \pm 0.09^{\mathrm{b}}$ & $0.42 \pm 0.07^{\mathrm{c}}$ \\
Cervical papillae width & $0.38 \pm 0.08^{\mathrm{a}}$ & $0.36 \pm 0.06^{\mathrm{a}}$ & $0.33 \pm 0.08^{\mathrm{b}}$ \\
Vulva length & $4.67 \pm 0.31^{\mathrm{a}}$ & $4.12 \pm 0.22^{\mathrm{a}}$ & $3.87 \pm 0.67^{\mathrm{b}}$ \\
\hline
\end{tabular}

$a, b, c$ Different superscripts within row indicate significant differences $(p<0.05)$. The number of worms measured for each concentration is $25, \mathrm{H}$. contortus=Haemonchus contortus, G. apus=Gigantochloa apus

Table-2: Morphometry of male $H$. contortus adult worms due to the administration of bamboo leaves crude aqueous extract.

\begin{tabular}{lccc}
\hline Worm morphometry & Control $(\mathbf{0} \%)$ & $\begin{array}{c}\mathbf{0 . 1} \mathbf{~ m g} / \mathbf{m l ~ G . ~ a p u s ~ c r u d e} \\
\text { aqueous extract } \mathbf{( m m})\end{array}$ & $\begin{array}{c}\mathbf{1} \mathbf{~ m g} / \mathbf{m l} \text { G. apus crude } \\
\text { aqueous extract( } \mathbf{~ m m})\end{array}$ \\
\hline Body length & $17.25 \pm 0.79^{\mathrm{a}}$ & $16.30 \pm 0.71^{\mathrm{b}}$ & $14.30 \pm 1.85^{\mathrm{c}}$ \\
Body width & $0.29 \pm 0.06^{\mathrm{a}}$ & $0.22 \pm 0.05^{\mathrm{b}}$ & $0.20 \pm 0.04^{\mathrm{b}}$ \\
Cervical papillae width & $0.44 \pm 0.03^{\mathrm{a}}$ & $0.41 \pm 0.06^{\mathrm{a}}$ & $0.38 \pm 0.08^{\mathrm{b}}$ \\
Spicula length & $0.52 \pm 0.01^{\mathrm{a}}$ & $0.42 \pm 0.22^{\mathrm{a}}$ & $0.38 \pm 0.07^{\mathrm{b}}$ \\
Gubernaculum length & $0.22 \pm 0.02^{\mathrm{a}}$ & $0.20 \pm 0.01^{\mathrm{a}}$ & $0.18 \pm 0.03^{\mathrm{a}}$ \\
\hline
\end{tabular}

$a, b, c$ Different superscripts within row indicate significant differences $(p<0.05)$. The number of worms measured for each concentration is $25, \mathrm{H}$. contortus=Haemonchus contortus, G. apus=Gigantochloa apus

difference in body length, body width, cervical papillae, and spicule length in male. There is no significant difference for gubernaculum length. G. apus crude aqueous extract at concentration of $0.1 \mathrm{mg} / \mathrm{ml}$ and $1 \mathrm{mg} / \mathrm{ml}$ is able to shorten the body length and spicule length. G. apus crude aqueous extract was decreased the body width in male adult worms.

\section{Discussion}

From the last study about $H$. contortus morphology [1], the shape is observed to be similar to the morphology of $H$. contortus with Reyaz [10] characters including color, total length, maximum width, spicule length, vulva length, gubernaculum length, and cervical papillae width.

Based on Table-2, it can be determined that there is a significant difference in the body width and body length of female $H$. contortus adult worms among the concentration of $0.1 \mathrm{mg} / \mathrm{ml}, 1 \mathrm{mg} / \mathrm{ml}$, and $0 \mathrm{mg} /$ $\mathrm{ml}$ (control). On the width of cervical papillae, there is no significant difference between the concentration of $0.1 \mathrm{mg} / \mathrm{ml}$ and $0 \mathrm{mg} / \mathrm{ml}$ (control), but at the concentration of $1 \mathrm{mg} / \mathrm{ml}$, G. apus crude aqueous extract has a significant difference to the control. The length of vulva has no significant difference at the concentration of $0.1 \mathrm{mg} / \mathrm{ml}$ to the control, but the concentration of $1 \mathrm{mg} / \mathrm{ml}$ has a significant difference to the control. The concentration of $1 \mathrm{mg} / \mathrm{ml}$ also has a significant difference to the concentration of $0.1 \mathrm{mg} / \mathrm{ml}$ in G. apus crude aqueous extract. The cuticle's damage caused by tannins contained in apus bamboo leaves can decrease the length of the worm's body, the body width, the width of cervical papillae, and the length of vulva. The tannin disturbs the physiology process of nematodes by binding nematode protein directly and subsequently [11].

Preliminary phytochemical screening of G. apus revealed saponin, alkaloid, flavonoid, and tannin.
Tannin in G. apus can influence both directly and indirectly with adult worms. Direct reaction happens by attaching their cuticle and causing distress, while indirectly reaction happens by improving protein nutrition [12].

Tannins on apus bamboo leaves play a role in binding proteins and turning nematode walls into inactivity and killing them as reported by Hoste et al. [13]. In addition, Molan et al. [14] proved that condensed tannins may have different effects on ruminants when consumed by the growth of adult worms and larvae. Calvin et al. [15] showed that condensed tannins have anthelmintic activity with varied possible mechanism of actions, most especially astringent property.

Microscopic observation on $H$. contortus morphometry indicates that it has a significant difference about body length, body width, cervical papillae width, gubernaculum, and spicule length in male worms (Table-2). G. apus crude aqueous extract concentrations of $1 \mathrm{mg} / \mathrm{ml}$ and $0.1 \mathrm{mg} / \mathrm{ml}$ were able to shorten the body length of male adult worms. Both the concentrations of bamboo leaf crude aqueous extract, $0.1 \mathrm{mg} / \mathrm{ml}$ and $1 \mathrm{mg} / \mathrm{ml}$, have a significant difference to the control, especially in the body length, cervical papillae width, and spicule length. The length of spicules has a significant difference between $G$. apus crude aqueous extract at the concentration of $1 \mathrm{mg} / \mathrm{ml}$ $(0.38 \pm 0.07)$ versus $0.1 \mathrm{mg} / \mathrm{ml}(0.42 \% \pm 0.22)$ and at the concentration of $1 \mathrm{mg} / \mathrm{ml}$ versus control $(0.52 \pm 0.01)$, but there was no significant difference between the length of spicules of worm exposed to $0.1 \mathrm{mg} / \mathrm{ml}$ concentration and those of the control. The width of cervical papillae in male $H$. contortus adult worms differed significantly between the dose of $1 \mathrm{mg} / \mathrm{ml}$ G. apus crude aqueous extract $(0.38 \pm 0.08)$ and the dose of $0.1 \mathrm{mg} / \mathrm{ml}(0.41 \pm 0.06)$, as well as between 
the dose of $1 \mathrm{mg} / \mathrm{ml}$ and the control $(0.44 \pm 0.03)$, but there was no significant difference between $0.1 \mathrm{mg} / \mathrm{ml}$ dose and the control on width of cervical papillae. The presence of many morphometric differences between different doses and control may be due to the effect of tannins in G. apus crude aqueous extract that can damage the adult worm's cuticle, interfering with the digestion process. The cuticle change with the longitudinal and transverse wrinkles after in vitro exposure to Biophytum persianum rich in condensed tannin on H. contortus was evaluated by Sambodo et al. [16] crude extract. The wrinkles in the cuticle and anterior end of $H$. contortus were also observed by MartinezOrtiz-de-Montellano et al. [17]. The cuticle reveals the form of adult worms and also involved in its motility and the exchanges with the parasite environment, including the metabolic exchanges with the local environment in the digestion tract of the host [1].

\section{Conclusion}

G. apus crude aqueous extract activity revealed morphology change and reduced morphometry measurement of $H$. contortus adult worms, notably in body length, body width, cervical papillae width, gubernaculum, and spicule length in males and body length, body width, cervical papillae width, and vulva length in females.

\section{Authors' Contributions}

The research was determined, managed, and supervised by KK. BPW took samples and recorded samples and sample analysis. WN, BPW, and KK arranged, analyzed, and wrote the report. JP worked overall observation of the experiment and the manuscript writing. All authors read and approved the final manuscript.

\section{Acknowledgments}

The authors would like to thank Mr. Abu Mas'ud for his goat's abomasum support for this research. Special thanks to the State of Agriculture Human Resources Development and Agriculture Extension, Ministry of Agriculture, Indonesia, for financial support through Domestic Graduate Scholarship Grant Number 547/Kpts/Kp.320/8/2016 Address: Jalan Harsono RM No 3 Gedung D Pasar Minggu Jakarta Selatan Indonesia.

\section{Competing Interests}

The authors declare that they have no competing interests.

\section{References}

1. Kuchai, J.A., Ahmad, F., Chishti, M.Z., Tak, H., Ahmad, J.A.S. and Razool, M. (2012) A study on morphology and morphometry of Haemonchus contortus. Pak. J. Zool., 44(6): 1737-1741.

2. Mengist, Z., Abebe, N., Gugsa, G. and Kumar, N. (2014)
Assesment of small ruminant haemonchosis and its associated risk factors in and around Finote selam, Ethiopia. IOSR JAVS, 7(12): 36-41.

3. Nasai, N.B., Abba, Y., Abdullah, F.F.J., Marimuthu, M., Tijjani, A., Sadiq, M.A., Mohammed, K., Chung, E.L.T. and Omar, M.A.B. (2016) In vitro larvicidal effects of ethanolic extract of Curcuma longa Linn. On Haemonchus larval stage. Vet. World, 9(4): 417-420.

4. FAO. (1991) Food Losses Due to Non-infectious and Production Diseases in Developing Countries. FAO, United Nations.

5. Alemu, Z., Kechero,Y., Kabede, A. and dan Muhammed, A. (2014) Comparison of the in vitro inhibitory effect of doses of tannin rich plant extract and ivermectin on egg hatchability, larvae development, and adult Mortality of Haemonchus contortus. Acta Parasitol. Glob., 5(3): 160-168.

6. Alawa, C.B.I., Adamu, A.M., Gefu, J.O., Ajanusi, O.J., Abdu, P.A., Chiezy, N.P., Alawa, J.N. and dan Bowman, D.D. (2003) In vitro screening of two Nigerian medicinal plants (Vernona amygdalina and Annona senegalensis) for anthelmintic activity. J. Vet. Parasitol., 113: 73-81.

7. Akkari, H., Darghout, M.A. and Salem, H.B. (2008) Preliminary investigations of the anti-nematode activity of Acacia cyanophylla Lindl.: Excretion gastrointestinal nematode eggs in lambs browsing A. cyanophulla with and without PEG or grazing native grass. J. Small Rum. Res., 74(b): 78-83.

8. Suratiningsih, S., Rahayu, S.M. and Suhartati, F.M. (2013) Supplementation ethanol extract bamboo leaves Petung (Dendrocalamus asper) effect on concentration of N-NH3 and VFA total in in vitro. J. Sci. Ranch, 1(2): 590-596.

9. Daryatmo, J., Hartadi, H., Orskov, E.R., Adiwimarta, K., and Nurcahyo, W. (2010) screening of various forages for anthelmintic activity of Haemonchus contortus eggs. Adv. Anim. Biosci., 1: 113.

10. Reyaz, A. (2005) Epidemiology, Biology, and Pathogenicity of Nematodes in Ruminants of Kashmir. M.Phil. Dissertations. University of Kashmir.

11. Min, B.R., Barry, T.N., Attwood, G.T. and Menabb, W.C. (2003) The effect of condensed tannin on the nutrition of ruminants fed fresh temperates forages: A review. Anim. Feed Sci. Tech., 106: 3-19.

12. Zhong, R.Z., Sun, H.X., Liu, H.W. and Zhou, D.W. (2014) Effects of tannin acid on Haemonchus contortus larvae viability and immune responses of sheep white blood cells in vitro. Parasite Immunol., 36: 100-106.

13. Hoste, H., Jackson, F., Athanasiadou, S., Thamsborg, S.M. and Hoskin, S.O. (2006) The effect of tannin-rich plants on parasitic nematodes in ruminants. Trend Parasitol., 22(6): 253-261.

14. Molan, A.L., Waghorn, G.C. and McNabb, W.C. (2009) Condensed tannin and gastrointestinal parasites in sheep. Proc. N. Z. Soc. Anim. Prod., 69: 89-92.

15. Calvin, B.Z., Abiodoun, O.P., Georcelin, A.G., Laure, A.N., Purtrand, J.A., Blaise, A.G. and Sylvie, H.A. (2016) In vitro anthelmintic activity of aqueous extract of Crasscephalum crepidioides (benth) S. Moore on Haemonchus contortus. J. Exp. Integr. Med., 6: 1.

16. Sambodo, P., Prastowo, J., Kurniasih, K. and Indarjulianto, S. (2018) In vitro potential anthelmintic activity of Biophytum petersianum on Haemonchus contortus. Vet. World, 11(1): $1-4$.

17. Martinez-Ortiz-de-Montellano, C., Arroyo-Lopez, C., Fourquaux, I., Torres-Acosta, J.F.J., Sandoval-Castro, C.A. and Hoste, H. (2013) Scanning electron microscopy of Haemonchus contortus exposed to tannin-rich plants under in vivo and in vitro conditions. Exp. Parasitol., 133(3): 281-286. 